\title{
Imaji Pop Surealisme: Figur Gendut dalam Lukisan
}

Wahyuddin Nafilah Dias Prabu

Amerge Creative Arts

Jln. As-Samawat No.178, RT.07

Kersan, Tirtonirmolo, Kasihan, Bantul, Yogyakarta

Tlp.082143145462,E-mail: 87diasprabu@gmail.com

Volume 4 Nomor 1,

April 2017: 36-48

\begin{abstract}
ABSTRAK
Tulisan ini mengangkat figur gendut sebagai ide dasar penciptaan seni lukis dengan menggunakan gaya pop surealisme. Penggabungan antara daya imajinasi tentang figur gendut dengan berbagai permasalahan yang bisa diangkat dari figur merupakan sebuah jalan dalam menciptakan karya-karya yang unik, terkadang satir, serta jenaka. Bentuk-bentuk kartunal yang digunakan dalam membuat figur gendut dan figurfigur lainnya merupakan satu tujuan khusus agar karya yang disampaikan memiliki unsur yang informatif terhadap para apresian. Menjadi gendut bagi setiap manusia yang mengalaminya sebenarnya bukan sebuah keinginan. Melalui berbagai perjalanan masa atau era yang bergulir hingga saat ini, persoalan tentang tubuh telah menuju pada bentuk yang indah dan ideal. Kecantikan dan ketampanan pada saat ini juga diukur pada orang-orang yang memiliki bentuk tubuh yang "normal" dan ramping. Bagi orang-orang yang memiliki kelebihan berat badan, tentunya jika diukur pada hal tersebut sangatlah tidak cocok. Figur gendut saat ini seperti diposisikan pada ruang yang sulit untuk mengeluarkan rasa percaya dirinya dalam menampik tentang apa yang diungkapkan di atas. Faktor kaum kapitalis dalam mendorong hadirnya pemikiran baru untuk hidup sehat tanpa menjadi gendut, juga semakin mengecilkan semangat orang-orang yang bertubuh gendut. Jika dilihat dari segi kesehatan, mungkin gendut terkesan seperti orang yang suka tidur, malas bekerja, dan sebagainya. Gendut berbeda dengan obesitas, karena obesitas merupakan penyakit kelebihan lemak di atas rata-rata yang membuat tubuh tak mampu mencerna makanan dalam berskala besar serta asupan makanan yang dikonsumsinya memiliki kalori yang sangat besar, sedangkan gendut merupakan kelebihan berat badan. Di sisi lain. gendut memiliki banyak kelebihan yang berguna dalam memajukan hidupnya dan mewujudkan citacitanya.
\end{abstract}

Kata kunci: figur gendut; kaum kapitalis; pop surealisme; kartunal

\section{ABSTRACT}

The Images of Pop Surealism: Fat Figures on Painting. This paper elevates the fat figures as the basic idea of painting creation by using pop surrealism style. The merging of the imagination of the fat figure with the various problems that can be lifted from the figure is a way to create unique works, sometimes satire, and funny. The cartoonous forms used in making fat figures and other figures are a special purpose for the work being delivered to have an informative element on the apresians. Being overweight for every human being is absolutely not anyone's desires. Through a variety of era of the rolling period to the present time, a matter of the body shape has led to a beautiful and ideal shape. Nowdays, beauty and good looks are a standard measured for people with "normal" and slim body. For people who are overweight, of course, this standard is not suitable. The current fat figure is positioned in a space where it is difficult to expend his confidence in dismissing what is described above. The capitalist factor encourages the emergence of new ideas for healthy living without becoming fat, also further discourages the people of the fat body. Being viewed in terms of health, the obese people seem like those who like to sleep, lazy to work, and so forth. Fat is different from obesity, because obesity is a disease of excess fat above the average that makes the body is unable to digest food in a large scale and 
intake of food has a very large calories, while the fat is overweight. On the other hand, fat has many useful advantages in advancing his life and realize his ideals.

Keywords: fat figure; the capitalist; pop surrealism; cartoons form

\section{Pendahuluan}

Setiap hadirnya sebuah pengalaman hidup yang mewarnai setiap individu manusia di dunia ini, merupakan sebuah langkah di mana pengalamanpengalaman tersebut akan menjadikan manusia itu sendiri menjadi lebih dewasa. Kusrini (2016) menyatakan bahwa objek seni bisa bersumber dari kehidupan yang kompleks, dapat berupa manusia, jajaran gedung-gedung dengan keunikan arsitektur, poster yang terkoyak, rambu-rambu lalu lintas, kendaraan yang lalu lalang, ataupun parkir di pinggir jalan, tempat sampah, grafiti berbagai corak di dinding-dinding. Objek-objek tersebut apabila dicermati, diteliti, dan diabadikan akan memiliki nilai humanis yang tidak terduga.

Demikian juga dengan tubuh manusia, banyak orang yang masih menganggap bahwa keindahan tubuh yang proporsional itu ialah langsing tanpa cacat. Pergeseran arti dan pengartian tentang sebuah kata "indah" untuk tubuh manusia hingga saat ini telah mengalami penerjemahan yang luas. Langsing, bertubuh kurus proporsional, indah dipandang, dengan ditambah paras yang menawan, akan menimbulkan sebuah panggilan bahwa orang tersebut tampan atau cantik. Sementara itu, orang yang bertubuh gendut, seperti ditempatkan pada sesuatu yang tidak nyaman. Orang-orang gendut sering dijadikan bahan canda dan panggilan aneh bagi teman-temannya sendiri.

Kesadaran akan mencintai dan menghormati sesama manusia merupakan salah satu kunci positif untuk mengapresiasi orang yang berlemak lebih (gendut). Refleksi problematika tentang figur gendut itu sendiri juga didapatkan penulis ketika pernah berinteraksi dengan orang-orang gendut yang pernah ditemui, kemudian mengambil beberapa hal yang bisa digali dari mereka. Setelah itu, akan disatukan dengan pemaknaan yang dibuat tentang bagaimana hubungan antara figur gendut dengan karya seni rupa. Penggabungan beberapa hal tersebut merupakan langkah awal yang nantinya akan muncul pengetahuan yang baik, jika dilihat dari segi keindahan melalui seni rupa, yaitu yang berhubungan dengan tubuh gendut. Tidak bermaksud juga untuk mengajak masyarakat untuk harus memiliki tubuh gendut (karena dari segi kesehatan itu juga tidak dianjurkan), namun ingin memberikan perspektif lain dalam dunia kesenirupaan.

Melihat sejarah pada masa renaisans dulu, figur gendut memiliki aura kecantikan bagi para seniman. Tubuh gendut pada era renaisans pada waktu itu banyak digunakan para seniman sebagai objek kekaryaannya. Figur gendut banyak dijadikan sebagai acuan para seniman dari era renaisans hingga sekarang. Figur gendut jika diaplikasikan menjadi sebuah karya seni mengandung unsur kebentukan yang padat, subur, dan figur yang menceriakan. Jika memang terkadang sebuah karya figur gendut digambarkan seperti dalam keadaan murung atau marah, itu dikarenakan konteks tubuh mereka bisa dijadikan alat publikasi untuk tetap peduli terhadap kesehatan.

Salah satu seniman yang juga mempelajari era renaisans dan kemudian menerapkan dalam kekaryaannya adalah Fernando Botero, seorang perupa yang berasal dari Kolombia, dan sudah banyak malang melintang, berpameran di manamana, serta tetap kokoh dengan ciri khas yang selalu dibawanya dalam kekaryaannya, yaitu tentang figur gendut (Gambar 1).

Ide dan bentuk gendut yang diciptakan Botero selain berasal dari pengamatan bentuk figur gaya Baroq yang ada di langit-langit gereja di daerahnya, juga merupakan hasil dari proses pembelajaran renaisans. Dunia telah mengakui bahwa Botero merupakan seniman bergaya figuratif dengan 
bentuk yang gendut. Karya-karya yang ia ciptakan banyak menceritakan kisah sejarah yang ada pada negaranya, namun terkadang dia juga membuat karya yang bernuansa religius, serta juga banyak menelurkan karya-karya still life yang unik, dengan gaya Botero sendiri. Bahkan karena keunikan dan keuletannya dalam memainkan pola figur gendut menjadi instrumen kekaryaannya, Fernando Botero telah banyak mendapat pengakuan dari berbagai negara. Dia juga telah banyak berpameran tunggal, dari Jerman, Meksiko, hingga Amerika Serikat.

Salah satu contoh karya lukis dari Botero dalam (Gambar 1) merupakan awalan bagi penulis dalam mengembangkan penulisan serta proses kreatif yang berhubungan dengan figur gendut, dan setelah itu mulai memasukkannya dalam imajinasi pop surealisme penulis pada kekaryaannya sendiri. Sekaligus dapat menjadi pembeda antara referensi karya dari Botero, dengan karya lukis dari penulis (Gambar 2).

Pandangan subjektif sering terjadi pada orang yang bertubuh gendut di kalangan masyarakat saat ini. Akan tetapi, ada beberapa persoalan lain bisa dijadikan sebagai rumusan masalah (ide) penciptaan, antara lain ialah: (a) bagaimana

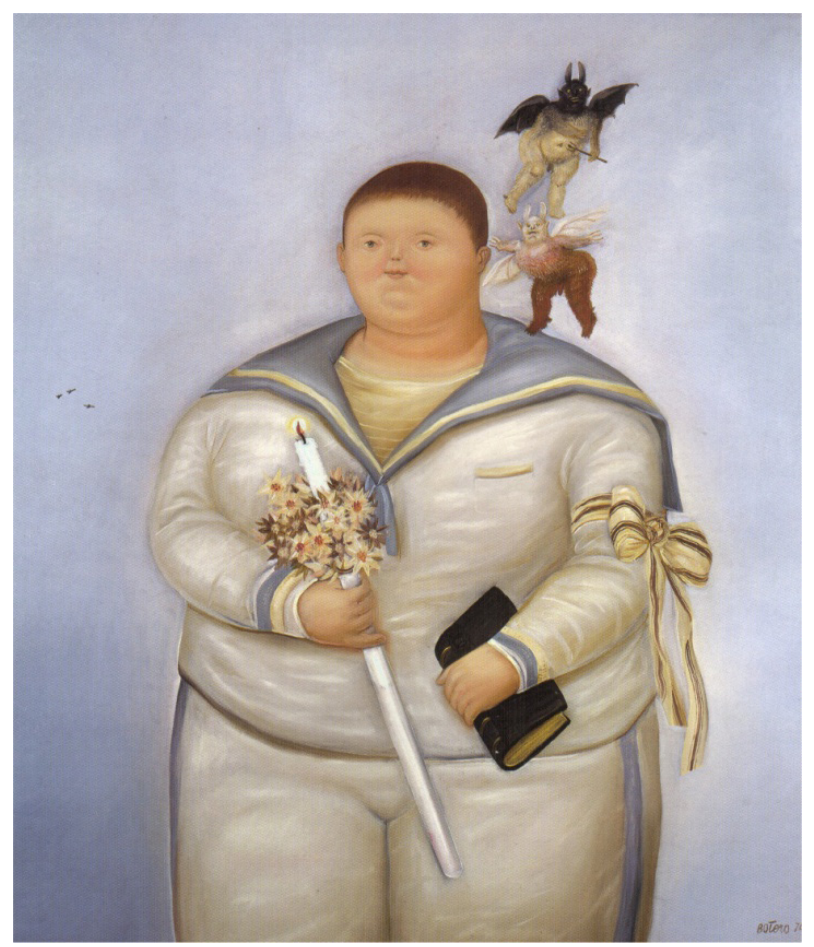

Gambar 1. Fernando Botero, Self-Portrait on the Day of First Communion, 1970, Cat minyak pada kanvas, $109 \mathrm{~cm}$ x $94 \mathrm{~cm}$, Sumber: Hanstein (2007) (difoto oleh: Dewi Bukit 2012) menciptakan karya lukis dengan objek utama figur gendut berdaya tarik pop surealisme yang jenaka dan segar, namun mempunyai makna mendalam dan (b) apa saja hal-hal atau fakta yang dapat diungkapkan menggunakan metafor (objek dan bentuk) tubuh gendut.

Tujuan karya ini adalah: (a) menciptakan figur gendut bergaya pop surealisme yang jenaka, segar, dan unik, namun tetap memiliki makna yang mendalam pada kekaryaan dan (b) membangun eksistensi pribadi (kesenimanan), dengan selalu menghadirkan karya-karya yang kreatif, segar, dan jenaka tentang figur gendut bergaya pop surealisme serta tetap menjaga konsistensi dalam berkarya seni. Manfaat dari penciptaan seni lukis ini ialah: (a) memperkaya khazanah seni rupa dalam pencitraan dan penciptaan seni rupa bertemakan figur gendut yang bermakna positif, (b) melahirkan kesadaran akan pentingnya saling menghormati antarsesama manusia, tanpa perlu melihat kekurangannya, dan (c) melahirkan kesadaran kreatif mengenai penciptaan karya dengan peran utama figur gendut melalui gaya pop surealisme yang lebih jenaka, segar, dan makna yang diungkapkan juga bermanfaat bagi semuanya.

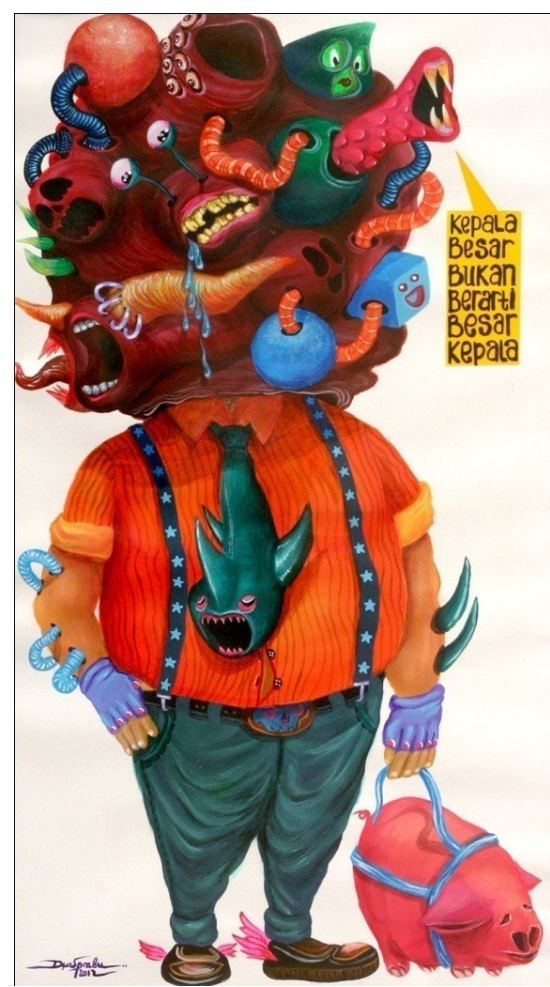

Gambar 2. Don't look the big just from the body, 2012, Cat akrilik, cat poster, dan tinta pada kertas, $70 \mathrm{~cm}$ x $37 \mathrm{~cm}$. Difoto oleh: Dewi Bukit 2012 


\section{Konsep Penciptaan}

\section{A. Kajian Sumber Penciptaan}

Proses dalam kehidupan telah memberikan satu pertanyaan, yaitu bagaimana memberikan atau meningkatkan rasa percaya diri dan menumbuhkan semangat juang bagi orangorang yang bertubuh gendut dalam menggapai mimpi dan cita-citanya. Keadaan yang terjadi pada era urban saat ini juga turut memacu untuk mengolah imajinasi dan kreatifitas, terutama dalam menciptakan karya seni bergaya pop surealisme, yaitu "Imaji Pop Surealisme Figur Gendut dalam Lukisan”.

\section{Imaji dan Imajinasi}

Secara umum yang dimaksudkan dengan istilah imaji menurut Tedjoworo (2001: 1) ialah citra atau gambaran. Adapun yang dimaksud dengan imajinasi menurutnya ialah daya untuk membentuk gambaran atau konsep-konsep mental yang tidak secara langsung didapatkan dari sensasi pengindraan.

Proses kreatif seniman dalam dunia seni rupa merupakan sebuah langkah dalam membangun imajinasi-imajinasi dalam pemikirannya. Pandangan tentang hubungan antara imaji dan imajinasi tersebut juga dikuatkan oleh penjelasan dari Jean-Paul Sartre berikut ini:

...objek imaji itu dibatasi oleh kesadaran: tidak ada yang dapat dipelajari dari sebuah imaji yang belum diketahui. Tentu saja bisa terjadi bahwa sebuah memory imaji, pengalaman sebelumnya tentang sebuah objek hidup kembali sekarang tanpa kehadiran objek itu sendiri, bisa muncul secara tak terduga dan sekaligus memunculkan aspek-aspek baru (Sartre, 2000).

Berawal dari pengertian tersebut, permainan imajinasi dalam membuat sebuah karya seni yang unik dan menarik tentang figur gendut merupakan pondasi yang dibuat untuk kemudian dilanjutkan kepada bagaimana mengaplikasikan imaji dan imajinasi tentang tubuh figur gendut menjadi sebuah karya seni yang indah.

\section{Tubuh}

Tubuh bukan hanya kulit dan tulang, yang terangkai menjadi satu bagian utuh, melainkan juga merupakan sebuah diri pribadi. Seperti yang dijelaskan oleh Synnott berikut:

Seperti organ dan bagian tubuh, atribut tubuh sesungguhnya juga bersifat sosial. Usia, gender, dan warna kulit merupakan penentu utama hidup dan identitas sosial kita, menjadi titik utama bagi konsep-diri dan konsep kelompok-kita. Dengan cara yang sama, atribut-atribut unik mengenai kecantikan, ketidakmenarikan, tinggi badan, berat badan, dan cacat fisik, jika ada, tidak hanya memengaruhi berbagai respons sosial atas diri, melainkan juga memengaruhi kesempatan hidup kita. Dengan demikian, tubuh menjadi simbol utama diri dan penentu diri yang utama (Anthony, 2007: 2).

Tubuh dalam diri manusia merupakan sesuatu yang bisa dibilang kompleks bahkan rumit. Pandangan ini sesuai dengan apa yang dikemukakan oleh Baudrillard (2009: 169), yaitu tubuh "yang diserasikan kembali" langsung berada dalam fungsi objektif "kapitalis". Dengan kata lain, jika tubuh ditanamkan sebagai modal, hal ini agar membuatnya mendatangkan keuntungan.

\section{Figur Gendut}

Kata figur jika diartikan adalah sesuatu sosok atau objek. Figur menurut Susanto (2011:136) ialah objek yang berbentuk dan memiliki kesamaan dengan suatu tanda tertentu (seperti manusia, hewan, tumbuhan, atau lainnya) yang masih merujuk benda yang telah ada. Maka, arti dari figur gendut ialah sosok yang memiliki tubuh dengan berat badan yang berlebih. Konteks ini ditujukan pada manusia, sebagai pembahasan dalam tulisan ini.

Dalam dunia seni rupa, gendut pada masa renaissans dulu sangat diagung-agungkan oleh para seniman sebagai objek kekaryaannya. Selain itu, orang yang memiliki tubuh gendut pada masa renaissans akan menjadi pusat perhatian di kalangan masyarakat. Gendut pada masa 
itu merupakan sebuah bentuk tubuh yang memancarkan kecantikan serta keindahan yang mendalam. Seniman seperti Rubens dan Renoir sangat sering melukis figur-figur gendut karena pada waktu itu bentuk tubuh yang gendut melambangkan kesuburan, keindahan yang mendalam, dan justru sebagai kesehatan yang baik. Pandangan tersebut juga dikuatkan oleh Fernando Botero yang dikutip Mariana Hanstein berikut ini:

..." "fat" is associated with positive qualities such as health, affluence, joie de vivre. Fat people are associated with good moods, sensuous pleasures and good-naturedness. Certainly Botero plays with the cliche of a continent of festivals and color, of the siesta and of good food. And accordingly the reaction of beholders of his works is mostly cheerful and relaxed (Hanstein, 2007: 54).

Menurut pengertian tersebut, Fernando Botero memosisikan gendut sebagai sesuatu yang menyehatkan, kenikmatan yang mendalam, serta bentuk yang sangat alami. Apa yang diungkapkan oleh Botero tersebut semakin memberikan semangat tersendiri dalam menelusuri serta memaknai figur gendut yang kemudian penulis kreasikan menjadi kekaryaan.

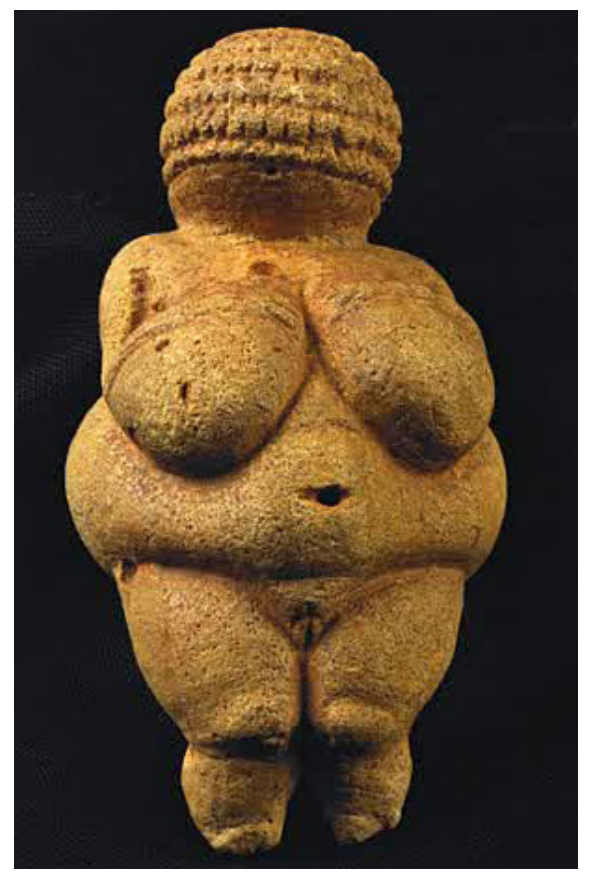

Gambar 3. Patung Venus dari Willendorf (Sumber: www.kenney-mencher.com) Disunting oleh: Dias Prabu, 20 Januari 2011
Sejarah figur gendut telah bisa ditelusuri pada masa 25 ribu hingga 30 ribu tahun Sebelum Masehi, ketika manusia masih menyembah patung "Venus dari Willendorf" (Gambar 3). Patung ini ditemukan oleh arkeolog Joseph Szombathy pada tahun 1908 di sebuah lokasi dekat Willendorf, Austria. Patung ini dulunya merupakan sesembahan untuk kesuburan serta penjaga keindahan pada waktu itu. Bukti adanya patung gendut tersebut, sebenarnya bisa mewujudkan sebuah pengertian bahwa memang sebuah keindahan itu awalnya dinilai dari bentuk tubuh yang gendut.

Menurut Rosita (2008: 104), sebenarnya dulu anggapan gendut itu cantik dan indah telah ada sekurang-kurangnya di pedesaan Mauritania, kemudian pada zaman Dinasti Tang di Cina, serta pada abad 17 di Inggris. Masih banyak lagi contoh lain yang menjelaskan bahwa gendut itu cantik dan indah. Walaupun semua itu lambat laun semakin hilang oleh pergeseran budaya serta dorongan kaum kapitalis modern hingga saat ini. Beberapa contoh sejarah yang berhubungan dengan figur gendut, setidaknya memberikan pandangan bahwa gendut juga telah ada sejak masa silam.

\section{Pop Surealisme (Lowbrow Art)}

Gaya ini lahir juga karena sentuhan dari kaum "Dada” yang salah satu pencetusnya ialah Marchel Duchamp dan kemudian mengimbas ke zaman berikutnya, sekitar tahun 1970 hingga 1980-an di Inggris dan Amerika. Seni pop memandang budaya komersial sebagai materi mentah, sebuah sumber ide yang tak pernah habis atas hal-hal yang bersifat subjek piktoral. Seni pop banyak melukiskan ikon-ikon yang muncul di masyarakat, seperti komik, desain komersial, iklan, dan lain-lain yang kemudian ditumpahkan ke dalam kanvas atau seni grafis menjadi sebuah karya seni. Seniman yang menonjol di dalam seni pop ialah seperti Andy Warhol, Roy Lichtenstein, dan Jasper John. Adanya karya dan pemikiran tentang seni pop pulalah yang pada akhirnya lahir berbagai aliran seni seperti conceptual art, happening art, dan juga pop surrealism (pop surealisme). 
Pop art atau popular art dalam kekaryaannya cenderung menggunakan bahan-bahan yang dekat dengan manusia. Pop art adalah gaya seni yang cenderung mengekspresikan spirit dunia pada zamannya (tahun 1960-an). Seniman pop art tidak ragu untuk mengkritik beberapa kebobrokan zaman. Mereka mengangkat objek murni/steril sebagai model-model dan barang sehari-hari seperti bola lampu listrik, kaleng bir, dan bungkus makanan.

Walaupun bahan yang digunakan hanya seperti itu, para seniman pop tetap indah dalam pengerjaan dari bentuk hingga maksud dari karya disampaikan. Kebebasan dalam berkarya dan permainan ide yang ditujukan pada apa yang terjadi di dunia saat ini merupakan ciri khas karya seni bergaya pop, yang pada akhirnya seiring perkembangan zaman, seni pop itu sendiri masuk pada pemikiran orang-orang yang menginginkan kebebasan dalam berkarya seni. Termasuk juga orang-orang yang masih dalam dunia pop tetapi juga mengandalkan gaya surealismenya dalam kekaryaannya.

Berawal dari seni pop itulah, lahir sebuah gaya dalam seni rupa, yaitu pop surealisme. Menurut Susanto (2011: 315), pop surealisme ialah lowbrow art. Pop surealisme atau sekarang lebih dikenal dengan lowbrow art, lahir dari budaya jalanan dan komunitas jalanan. Karyakarya pop surealisme memang sangat terinspirasi oleh ketidaknyamanan dalam menanggapi situasi

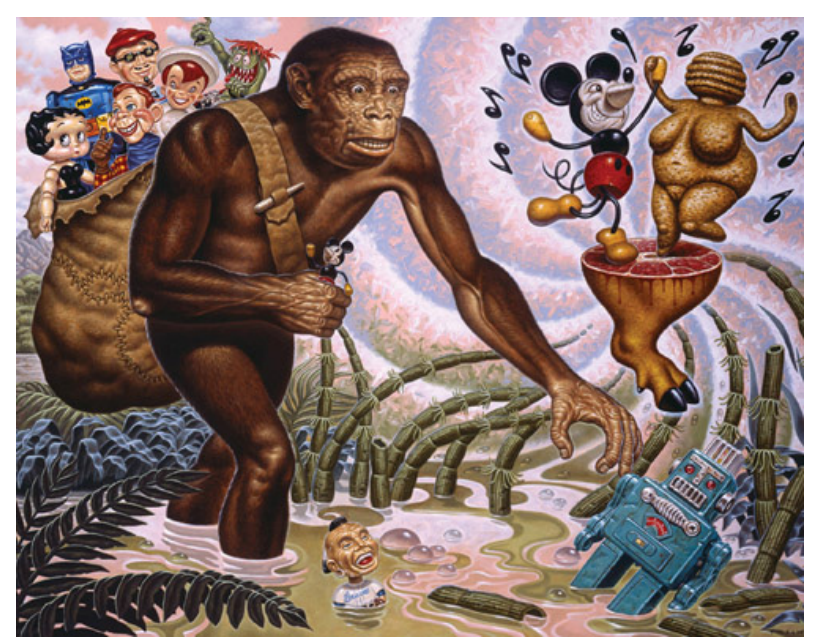

Gambar 4. Todd Schorr, The Hunter Gatherer, 1998, Cat akrilik pada kanvas, $80 \mathrm{~cm} \times 100 \mathrm{~cm}$, Sumber: Robert William (difoto oleh: Dias Prabu, 2012) politik, sosial, dan ikon budaya yang sedang populer di negara Amerika Serikat pada waktu itu. Akan tetapi, karya-karya yang diungkapkan selalu dibentuk dengan rasa humor yang tinggi dan terkadang sinis.

Lowbrow art lahir pada tahun 1994 oleh seniman Robert Williams yang juga pendiri majalah Juxtapoz, yaitu majalah yang membahas mengenai lowbrow art. Gerakan ini terinspirasi oleh film kartun era 60-an, komedi televisi, musik psycadelic, komik, film horor dan kartun animasi. Seniman lain yang bergaya pop surealisme saat ini seperti, Yosuke Ueno, Todd Schorr, Mark Rayden, dan Joe Sorren.

In keeping with narrative quality, lowbrow art is nearly always figurative, representational,. These paintings represent people, places, and things in the world and are rarely abstract. Many lowbrow artist have worked as illustrators, creating figurative art for album covers, magazines, and concept posters. As fine artist, they use their skills at creating representational images to give from to their ticklish, tormented, personal visions. (Jordan, 2005:12)

Definisi tersebut menjelaskan bahwa karya seni lowbrow selalu banyak berisi narasi cerita figuratif dan representatif, yang di dalamnya banyak berisi muatan lucu, jenaka, sarkastik, satir, bahkan tidak masuk akal.

Gambar 4 merupakan salah satu contoh karya dari seniman Todd Schorr beraliran pop surealisme (lowbrow). Karya tersebut menggambarkan manusia peradaban lama yang sedang menangkap superhero-superhero pada peradaban baru (masa sekarang).

\section{B. Cara Perwujudan dan Gagasan Kekaryaan}

Setiap hubungan dalam sebuah karya seni, antara ide, landasan penciptaan, konsep kebentukan, dan perwujudan haruslah memiliki keterkaitan antara satu dengan yang lain. Perwujudan tersebut haruslah bisa tersampaikan dengan baik kepada masyarakat penikmat seni yang melihat karya seni tersebut. Karena di sini walaupun melalui karya-karya yang terkesan jenaka dan terkadang 
menyindir, konteks sosialnya tetap dengan tujuan mengubah persepsi yang buruk menjadi baik tentang figur gendut itu sendiri. Konsep tentang bagaimana cara menyajikan bentuk-bentuk baru, juga akan menjadi daya tarik tersendiri nantinya. Bentuk-bentuk baru tersebut misalnya, membuat patung tiga dimensi dan melukis di atas kanvas yang berbentuk koper.

\section{Figur-Figur Kartunal sebagai Pencitraan Karya}

Perkembangan gambar-gambar kartunal dari masa ke masa telah mengalami banyak perubahan yang sigifikan. Kartun telah mewarnai berbagai film animasi serta cerita-cerita komik ataupun majalah di seluruh dunia. Wijana (2004:5) menjelaskan bahwa kartun itu seperti halnya monumen, ritus, film, dan advertasi, yang merupakan bentuk komunikasi politik. Kartun biasanya diciptakan sebagai reaksi terhadap peristiwa sejarah tertentu sehingga memungkinkan digali atau dicari faktanya. Banyaknya superhero yang ada dalam film, komik, dan majalah yang ada sekarang, memberikan ide kepada penulis untuk mencoba mentransformasikannya menjadi bentuk-bentuk tentang figur gendut kartunal dalam lukisan. Karya-karya bergaya pop surealisme, kini telah memasuki masa yang indah karena semakin banyak perupa yang berkarya dengan gaya tersebut.

\section{Warna-Warni sebagai Elemen Penting dalam Karya}

Warna merupakan salah satu elemen atau medium penting dalam seni rupa. Warna, menurut Dharsono (2007:76), dibagi menjadi tiga unsur utama, yaitu: (a) warna sebagai warna artinya kehadiran sebuah warna hanyalah untuk memberi tanda pada suatu benda maupun barang, atau hanya untuk membedakan ciri benda satu dengan lainnya tanpa maksud tertentu dan lebih dari itu hanya sebagai pemanis permukaan, (b) warna sebagai representasi alam artinya kehadiran warna merupakan penggambaran sifat objek secara nyata, atau penggambaran dari suatu objek alam sesuai dengan apa yang dilihatnya misalnya warna hijau untuk menggambar daun, biru untuk laut, dan (c) warna sebagai tanda/lambang/ simbol artinya kehadiran warna sebagai lambang atau melambangkan sesuatu yang merupakan tradisi atau pola umum. Warna pada hal ini lebih menjelaskan arti dari warna itu sendiri.

Peran penting dari setiap warna yang digunakan penulis dalam mengaplikasikan karya lukis yang bermaterikan pop surealisme perlu diisi dengan warna-warna yang bervariasi. Warna cerah, panas, dan menceriakan sering digunakan di dalam kekaryaan yang diciptakan.

\section{Garis sebagai Kekuatan Tersendiri}

Menurut Wang (2006:25), garis adalah untaian panjang menerus dan biasanya konsisten, sedangkan yang dimaksud tarikan adalah garis yang agak pendek dan terputus-putus dalam berbagai kelebaran. Garis merupakan guratan yang tersisa pada medium gambar atau sketsa akibat pensil yang ditorehkan, garis pada dasarnya lebih luwes dan mengalir, sedangkan

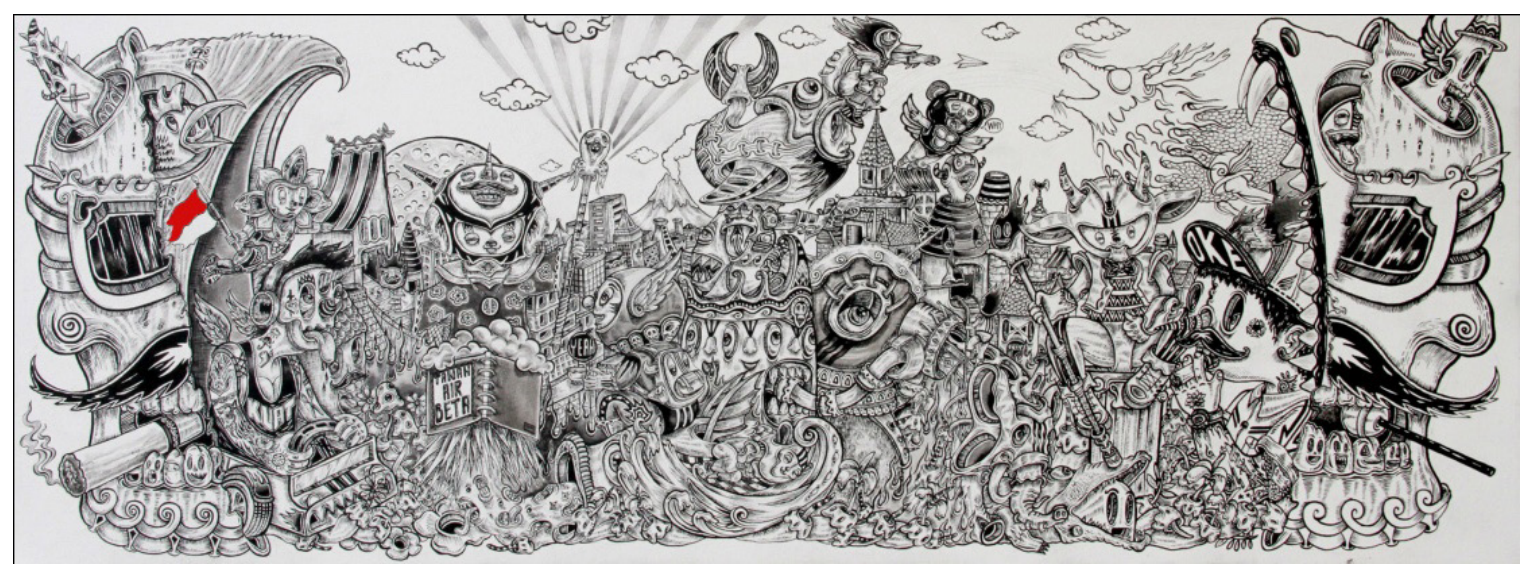

Gambar 5. Menengok Masa Depan, 2016, Cat akrilik dan tinta pada kanvas, $50 \mathrm{~cm}$ x $135 \mathrm{~cm}$, (difoto oleh: Dewi Bukit, 2016) 
tarikan sendiri cenderung guratan lurus yang patah-patah dan sering kali berwujud garis tebal dan tipis. Apa yang dijelaskan tentang arti dan kegunaan dari sebuah garis tersebut menunjukkan bahwa sangat pentingnya peranan garis dalam berbagai bidang apapun, terutama dalam dunia seni rupa. Penulis sangat mengedepankan faktor garis sebagai kekuatan dalam kekaryaannya dan itu menjadi daya tarik tersendiri untuk terus dieksplorasi terhadap segala bentuk ide yang akan dituangkan menjadi sebuah karya seni yang menarik. Gambar 5 adalah salah satu contoh karya penulis yang mengedepankan banyak garis sebagai kekuatan tersendiri.

\section{Proses Penciptaan}

Metode yang digunakan dalam proses penciptaan ini ialah metode yang lazim digunakan dan sistematis. Metode tersebut biasanya juga dipergunakan oleh perupa-perupa lainnya dalam proses penciptaannya. Proses penciptaan tersebut meliputi beberapa hal antara lain, eksplorasi, eksperimentasi (perumusan perancangan karya), kemudian tahap pembentukan karya, serta evaluasi. Tahap dari proses penciptaan karya tersebut dikerjakan secara berurutan dan terjadi pula proses improvisasi pembentukan dan penajaman estetik dengan kemampuan secara teknis maupun intuitif. Tahap-tahap tersebut jika dijelaskan secara berurutan tentang metode proses penciptaan, antara lain sebagai berikut.

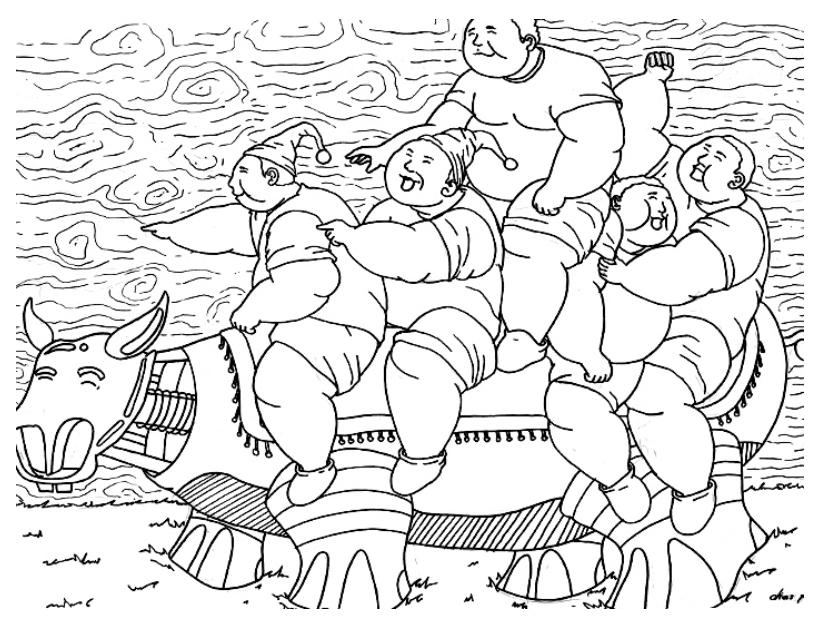

Gambar 6. Contoh sketsa tentang kebersamaan dalam figur gendut

(difoto oleh: Dias Prabu, 2012)

\section{A. Eksplorasi Ide}

Penggunaan figur gendut sebagai objek merupakan langkah awal penulis dalam mencurahkan ide dan imajinasi penulis dalam kekaryaan. Ide-ide yang muncul dalam pemikiran penulis tentang figur gendut berawal dari pengamatan baik itu secara sengaja maupun tidak sengaja. Pengamatan tersebut dalam proses eksplorasi ini tidak semata-mata mengandalkan pengamatan langsung terhadap masyarakat tertentu, tetapi juga melalui berbagai media massa, baik tulis maupun elektronik.

Setelah menemukan ide yang dirasa cocok untuk dijadikan sebuah karya seni tentang figur gendut, kemudian setelah itu ide tersebut dikumpulkan menjadi beberapa sketsa awal, sebelum diaplikasikan di atas kanvas. Tentunya, imajinasi di dalam sketsa-sketsa sederhana tersebut merupakan hasil dari pengamatan dan dari datadata yang penulis kumpulkan dan ketahui tentang figur gendut. Gambar 6 merupakan contoh sketsanya, hasil dari pengamatan dan permainan imajinasi.

\section{B. Perumusan Perancangan Karya}

Beberapa hal yang penulis temukan berkaitan dengan figur gendut antara lain: tubuh sebagai makna dan alat untuk menujukkan berbagai hal, figur yang bertubuh gendut sebagai objek utama kekaryaan, citra kartunal sebagai media informasi bagi audiens, serta gaya pop surealisme sebagai gaya dalam melukis figur gendut. Hal-hal inilah yang kemudian mengantarkan penulis untuk memiliki ide, yaitu dengan penggunaan media kanvas untuk pengaplikasian kekaryaannya. Point of interest pada karya-karya yang diciptakan penulis mayoritas ialah yang berupa figur berbentuk gendut. Penambahan garis-garis tegas yang menjadi outline pada bagian luar figur tersebut, bertujuan untuk tetap mengedepankan sisi kontras serta balance setiap elemen yang ada.

Selain karya lukis yang diciptakan, penulis juga bereksperimentasi dengan menciptakan karya tiga dimensional. Salah satunya ialah karya patung instalasi figur gendut. Karya patung tersebut sebelumnya juga berasal dari eksplorasi ide yang kemudian disketsa dahulu pada kertas 
kosong. Setelah disketsa, kemudian dilanjutkan dengan menggunakan bahan-bahan yang sekiranya berhubungan dengan konsep untuk karya patung tersebut. Bahan-bahan yang digunakan antara lain mini manekin, kain kanvas, dan aksesoris. Setelah dibentuk menyerupai patung yang diinginkan, proses akhir ialah penutupan seluruh tubuh patung menggunakan resin. Kegunaan resin di sini ialah sebagai penguat sekaligus perekat bahan-bahan patung tersebut. Gambar 7 merupakan hasil eksperimentasi dari karya patung tersebut.

Mengenai berbagai hal yang telah dijelaskan tentang proses penciptaan tersebut, perlu dijabarkan lebih mendalam lagi tentang alat dan bahan yang digunakan dalam membuat suatu karya. Berikut ini merupakan alat, bahan, dan teknik yang digunakan:

\section{Alat}

(a) kuas (dengan berbagai macam bentuk dan ukuran dari yang besar hingga yang terkecil), (b) pisau palet (digunakan dalam bermain tekstur), (c) kertas berpola (digunakan dalam permainan bentuk yang telah disesuaikan), (d) isolasi kertas (digunakan untuk membuat batas garis-garis tegas ketika karya sedang dikuas atau disemprot), dan (e) gunting (digunakan untuk memotong kain kanvas pada karya patung tiga dimensional).

\section{Bahan}

(a) cat akrilik (dengan berbagai warna cat yang digunakan dalam berkarya, tentunya cat akrilik yang berbasis air lebih cocok. Cat akrilik cepat dalam proses keringnya karya yang baru saja dikuas, selain itu warna-warna yang cerah bisa langsung saling dicampur, (b) cat semprot/spraypaint (digunakan untuk mencari kesan kilap/metallic pada karya dan juga kesan gliter yang ditampilkan oleh cat ini), (c) cat air (sering digunakan dalam kekaryaannya pada media kertas), (d) kanvas (merupakan media

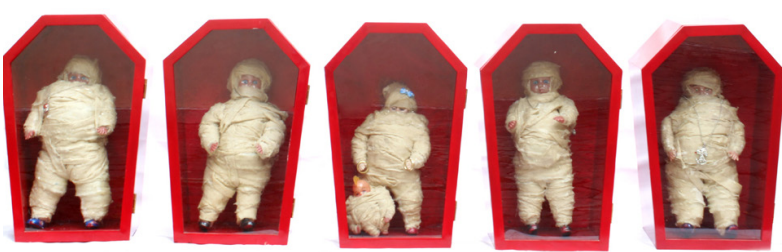

Gambar 7. Forever Rich, ukuran bervariasi (5 buah), boneka, kain kanvas, dan resin pada hardboard dan kaca (difoto oleh: Dewi Bukit, 2012) utama yang digunakan dalam melukis, serta untuk bahan pembalut tubuh mumi figur gendut pada karya patung tiga dimensional), (e) kertas (selain berguna sebagai sketsa awal penulis dalam berkarya, kertas juga dilukis oleh penulis menggunakan cat air), (f) resin (untuk melekatkan, menguatkan, sekaligus media finishing pada karya tiga dimensional), dan (g) boneka dan mini manekin (sebagai pencitraan patung yang dideformasi menjadi lebih gendut untuk karya tiga dimensional), (h) Dakron (digunakan untuk bahan pembentukan figure gendut pada karya tiga dimensional).

\section{Teknik}

Penggunaan teknik dalam melukis merupakan sebuah bagian yang penting dalam mewujudkan ide yang dirancang. Hal tersebut tentunya tetap bertumpu pada kepekaan serta penggunaan teknik yang tepat dalam pengerjaannya. Teknik yang sering digunakan pada setiap karya lukis penulis ialah teknik pewarnaan opaque. Susanto (2011:282) menjelaskan bahwa opaque merupakan teknik dalam melukis yang dilakukan dengan mencampur cat pada permukaan kanvas dengan sedikit pengencer. Dengan demikian, warna yang sebelumnya ada dapat tertutup atau tercampur. Penggunaan cat secara merata, tetapi mempunyai kemampuan menutup bidang atau warna yang dikehendaki. Beberapa contoh teknik

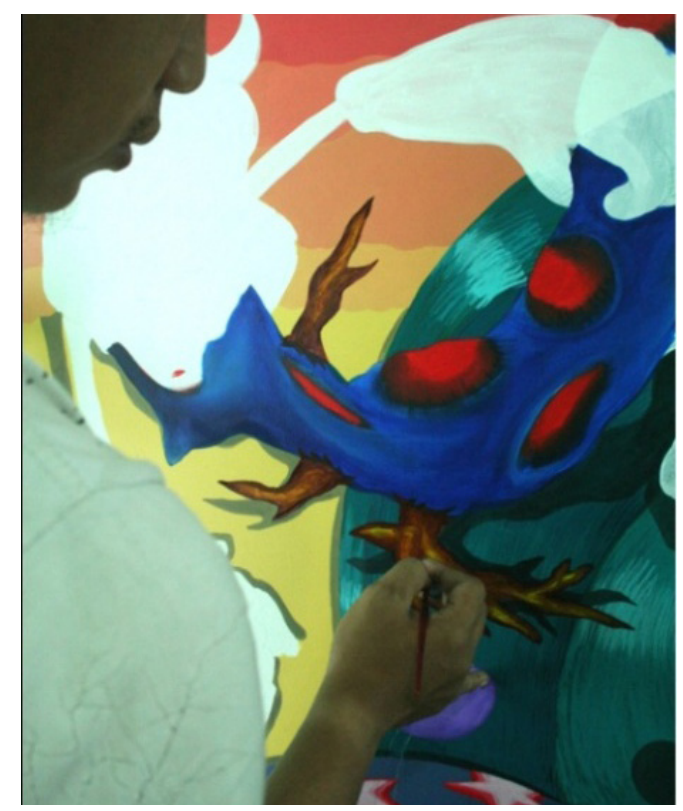

Gambar 8. Proses pewarnaan dengan menggunakan cat akrilik (difoto oleh: Dewi Bukit, 2011) 
yang menunjang teknik opaque ialah seperti, brushstroke, semprot, dusel, dan rol. Teknik ini juga berfungsi untuk membuat kesan lebih tegas serta merupakan kebalikan dari teknik aquarel.

\section{Tahap Penciptaan Karya}

Proses pembentukan karya yang diciptakan oleh penulis biasanya memakan hingga satu bulan, jika karya tersebut berukuran besar sekitar $200 \mathrm{~cm} \mathrm{x}$ $150 \mathrm{~cm}$. Akan tetapi, ada beberapa karya yang ukurannya kecil, pengerjaannya membutuhkan waktu sekitar dua minggu, namun itu semua tetap bergantung pada rasa dan emosi penulis dalam mengerjakan sebuah karya.

Selain menggunakan cat akrilik untuk melukis (seperti contoh gambar 10), ada beberapa bahan lain yang dikombinasikan untuk perwujudan karya, yaitu dengan spray paint atau cat semprot. Penggunaan tinta cina juga sangat disukai pelukis dalam membuat garis atau outline karena kepekatan warna hitam dalam tinta tersebut mampu memberikan dampak kekontrasan yang baik. Penggabungan antara warna-warna dari cat akrilik, kemudian ditambah dengan penggunaan garis-garis kuat dari hasil semprotan spray paint, serta pemanfaatan tekstur dari bahan-bahan sekitar merupakan perpaduan yang dilakukan penulis dalam berkarya seni.

Setelah melewati beberapa proses yang berurutan tersebut, pada tahap terakhir untuk perwujudan karyanya ialah dengan menggunakan frame atau pigura. Kegunaan frame selain untuk melindungi segala sisi dan sudut karya, frame bisa

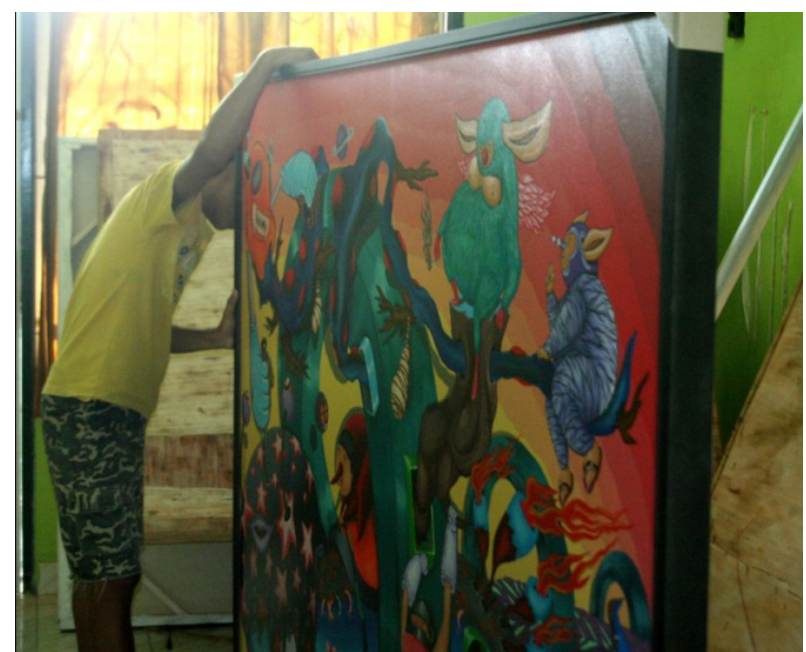

Gambar 9. Proses pemasangan frame pada karya (difoto oleh: Dewi Bukit, 2011) dikatakan dapat mempercantik karya itu sendiri. Gambar 9 merupakan salah satu contoh karya yang sudah dipasang frame.

\section{Hasil Penciptaan}

Gambar 10 sampai dengan gambar 13 merupakan beberapa karya lukis yang dihasilkan oleh penulis disertai dengan deskripsi pada setiap karya. Faktor yang sangat kental dalam beberapa karya ini ialah sosok figur gendut, sebagai ikon utama dalam kekaryaan. Selain itu, unsur kartunal dalam kekaryaan bergaya pop surealismenya, juga merupakan elemen penting di dalam penciptaan karya.

Gambar 10, pergeseran zaman yang semakin tidak terkendali di dunia saat ini telah sampai di titik nadir. Indonesia merupakan salah satu negara yang mengalaminya. Falsafah ketimuran yang sangat kental, kebudayaan yang sangat beragam di dalam negeri ini merupakan sebuah anugerah yang

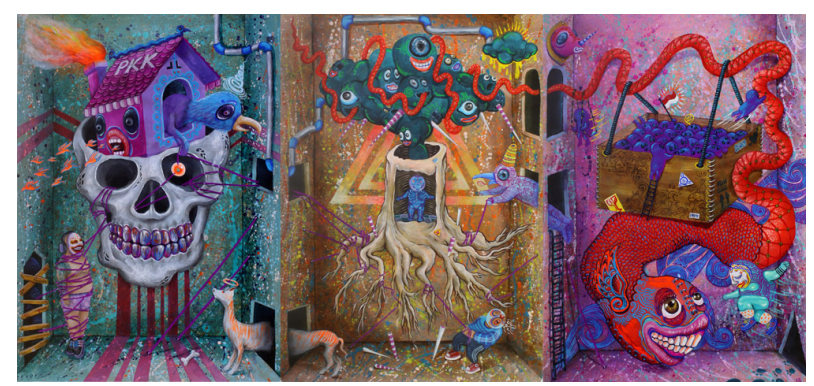

Gambar 10. Menakar Generasi Muda, 2014, Cat akrilik, cat poster, dan charcoal pada kertas, $68,5 \mathrm{~cm} \times 150 \mathrm{~cm}$ (triptych) (difoto oleh: Dewi Bukit, 2014)

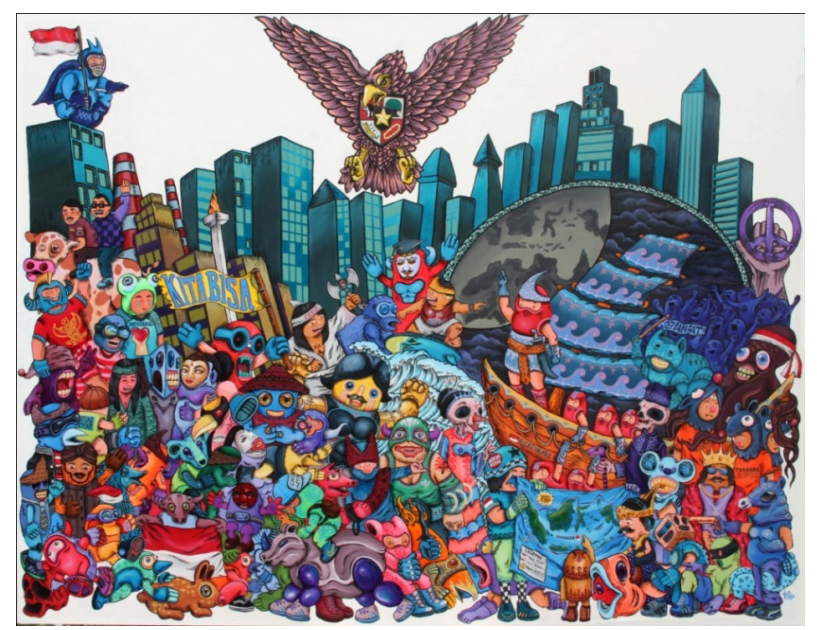

Gambar 11. Dari Kami untuk Negeri, 2015, Cat akrilik pada kanvas, $140 \mathrm{~cm} \times 180 \mathrm{~cm}$ (difoto oleh: Dewi Bukit, 2015) 
terindah. Oleh karena itu, kita wajib menjaganya dan mempertahankannya. Generasi baru akan terus bermunculan, begitu juga dengan perkembangan zaman juga tidak akan terelakkan.

Gambar 11, Indonesia merupakan negara yang memiliki sejuta pesona yang tiada tara. Keberagaman suku, agama, ras, budaya, dan bahasanya telah membuat bangsa ini menjadi sangat berwarna. Akan tetapi, di balik itu semua masih banyak persoalan pelik yang harus segera diselesaikan, dari ketimpangan sosial, perekonomian yang semakin memburuk, dan sebagainya. Perlu adanya semangat cinta, kepedulian yang tinggi, dan kerja sama yang baik dari segala elemen yang ada di negara ini. Terutama faktor penerus tongkat estafet bangsa ini, yaitu para pemuda dan pemudi di seluruh penjuru negeri. Semangat yang tumbuh dalam jiwa para pemuda dan pemudi Indonesia saat ini harus selalu bisa bersatu dengan ditanamkan pada hati mereka, yaitu semangat Bhinneka Tunggal Ika. Karena hal tersebut, akan membuat kita semakin cinta terhadap bangsa, tangguh dalam segala tantangan zaman, serta mampu mengharumkan Indonesia di mata dunia.

Gambar 12, bangsa yang besar selalu menghadirkan berbagai penerus bangsa yang harus diperhatikan dan jaga perkembangannya. Ketika menilai sebuah kelahiran, akan selalu muncul sebuah harapan besar di pundak mereka, di kala mereka besar nanti. Para penerus bangsa ini merupakan aset yang sangat berharga dalam melanjutkan

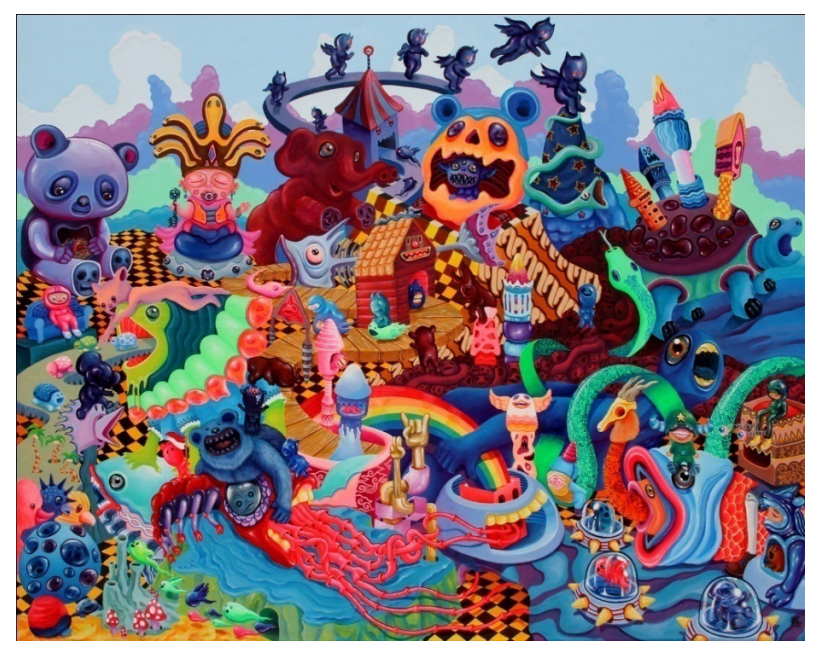

Gambar 12. Born Baby Born, 2015, Cat akrilik pada kanvas, $150 \mathrm{~cm}$ x $120 \mathrm{~cm}$ (difoto oleh: Dewi Bukit, 2015) tonggak kepemimpinan dan kemajuan di masa yang akan datang. Akan tetapi, terkadang apa yang dimimpikan bisa hancur seketika, jika tidak mampu dalam membina dan mendidik mereka. Adanya perjalanan hidup yang mereka lewati, tentunya tidak akan jauh dari segala permainan dan wahana yang mereka sukai pada waktu kecil. Hal tersebut dapat menumbuhkembangkan rasa keingintahuan mereka dalam memahami dan mampu memberikan efek yang positif ketika mereka bisa menentukan apa yang akan mereka kerjakan kelak.

Gambar 13, banyak yang bilang, bahwa tahun 2016 merupakan tahun perubahan dan tahun segala harapan, entah itu dalam bidang perekonomian, kesetaraan, dan sebagainya. Akan tetapi, banyak pula yang beranggapan bahwa pada tahun ini, masyarakat juga terkadang tidak bisa banyak berharap terhadap apa yang terjadi di negara saat ini. Jika mengambil satu titik pembahasan dari sisi hukum, akan terasa ada secercah harapan baru, bagaimana menjaga dan memperkuat sistem hukum kita seadil-adilnya hingga ke rakyat paling bawah sekalipun. Itu pun juga harus didorong oleh segala elemen masyarakat, untuk tetap memantau problematika kehidupan dan hukum di negara ini. Faktor utama dalam karya ini ialah sesosok penggambaran Dewi Justitia yang merepresentasikan sebuah keadilan, mengepalai sebuah kerajaan, dengan hukum di atas segalanya.

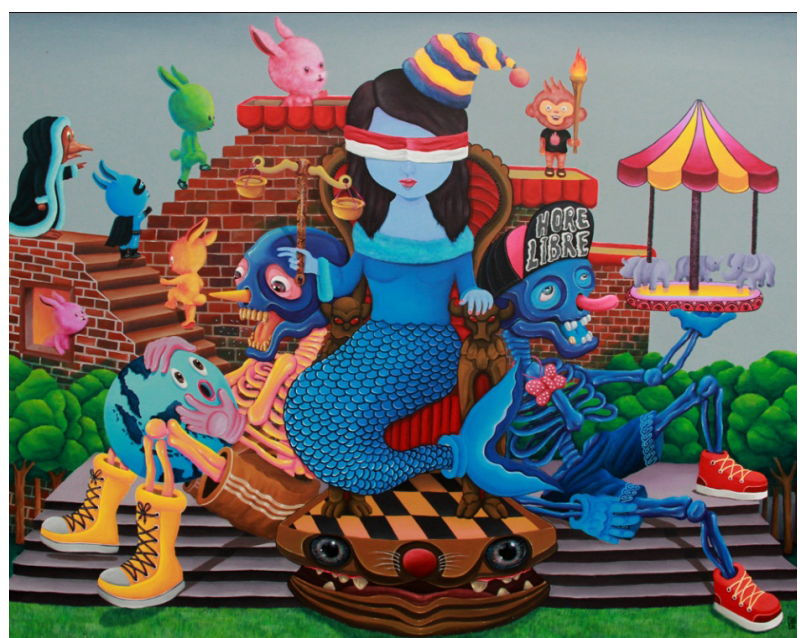

Gambar 13. Kingdom of Justice, 2016,

Cat akrilik dan tinta pada kanvas, $145 \mathrm{~cm}$ x $185 \mathrm{~cm}$ (difoto oleh: Dewi Bukit, 2016) 


\section{Simpulan}

Permainan imajinasi yang terangkum dalam pemikiran telah menghasilkan banyak potongan imaji tentang berbagai hal untuk dijadikan sebagai tonggak awal pembuatan sebuah karya seni. Imaji tersebut kemudian dikombinasikan dengan konsep utama yang diangkat, yaitu berhubungan dengan problematika yang ada dalam figur gendut, yang nantinya akan termanifestasikan menjadi karya seni yang diinginkan.

Posisi figur gendut di sini bukan hanya sebagai objek utama semata dalam kekaryaan saya, tetapi juga bisa sebagai metafora yang mencitrakan sesuatu hal. Bentukan kartunal pada figur-figur yang diciptakan lalu dikemas dengan gaya pop surealisme merupakan paduan yang pas untuk menciptakan karya yang nakal, menggelitik, satir, sekaligus jenaka, tentang problematika figur gendut. Hadirnya pop surealisme yang menjadi gaya kekaryaan merupakan cara yang tepat dalam mewakili kegelisahan penulis tentang figur gendut, bahkan hingga saat ini terus dipelajari dalam proses kekaryaannya.

Semua pemikiran dan proses kreatif tentang figur gendut tersebut telah memunculkan satu pandangan akhir. Seberat apa pun tubuh dalam meraih sebuah cita-cita, jika dilakukan dengan niat dan kerja keras, pasti akan dapat tercapai. Karena tubuh yang aktif dan berjiwa keras dalam meraih impian, tidak selalu tergambar pada bentuk tubuh yang ideal atau langsing semata, tetapi tubuh gendut juga memiliki hak tersebut. Melalui sebuah karya seni yang bertemakan tentang figur gendut, harapan yang paling baik untuk hal ini ialah setidaknya ada rasa toleransi yang tinggi terhadap satu sama lain, tanpa memandang bentuk tubuh atau kecantikan semata, karena Tuhan menciptakan seluruh manusia dengan segala kelebihan dan kekurangannya.

\section{Ucapan Terima Kasih}

Ucapan terima kasih penulis sampaikan kepada Prof. Drs. Soeprapto Soedjono, MFA. Ph.D. dan Dr. Edi Sunaryo, M.Sn atas pemberian semangat tanpa kenal lelah. Rasa terima kasih juga disampaikan Erianto, Ida Ayu, Anna Eager, Hirwan Mopilie, Aulia Syahron, Bayu Wardhana, Romy Setiawan, dan teman-teman pekerja kreatif di Amerge Creative Arts dan grup mural Foreverfat. yang telah memberikan dukungan tanpa henti.

\section{Kepustakaan}

Baudrillard, P. J. (2009). Masyarakat Konsumsi. Yogyakarta: Kreasi Wacana.

Hanstein, M. (2007). Botero. Cologne: Taschen.

Jordan, M. D. (2005). Weirdo Deluxe: the wild world of pop surrealism \& lowbrow art. Canada: Chronicle Books.

Kusrini. (2016). "Fotografi Jalanan: Membingkai Kota dalam Cerita". Journal of Urban Society's Arts, Volume 3( 2), 102-109. https://doi.org/ http://dx.doi.org/10.24821/jousa.v3i2.1482

Rosita, S. (2008). Gendut Itu Cantik. Yogyakarta: Ayyana.

Sartre, J. P. (2000). Psikologi Imajinasi. Yogyakarta: Bentang Budaya.

Susanto, M. (2011). Diksi Rupa. Yogyakarta: DictiArt Lab.

Swa Oetomo, K. (2011). Obesitas. Malang: UB Press.

Synnott, A. (2007). Tubuh Sosial. Yogyakarta: Jalasutra.

Tedjoworo, H. (2001). Imaji dan Imajinasi. Yogyakarta: Kanisius.

Wang, C. T. (2006). Sketsa Pensil. Jakarta: Erlangga.

Wijana, I. D. P. (2004). Kartun. Yogyakarta: Ombak.

Williams, R., Mc Cormick, C., \& Reid, L. (2004). Pop Surrealism: The Rise Of Underground Art. Yogyakarta: Ignition Publishing.

\section{Pustaka Laman}

Dyball, Rennie. My Big Fat Fabulous Life Star: I'm Not Promoting Obesity. 2015. http://www. people.com/article/my-big-fat-fabulous-lifewhitney-thore-tlc-season-two. (Diakses pada Minggu, 20 Desember 2015, pukul 15.30 WIB).

Mencher, Kenney. Woman from Willendorf, (Venus of Willendorf), Austria. http://www. 
kenney-mencher.com. (Diakses pada Kamis, 20 Januari 2011, pukul 19.15 WIB).

Natalie. Fat Talk! Plus size fashion promotes obesity? Whatever! http://extralargeaslife.com/2011/ fat-talk-size-fashion-promotes. (Diakses pada Senin, 21 Desember 2015, pukul 17.35 wib). No Title. (n.d.). Retrieved from http://www. kenney-mencher.com 